\title{
THE ARTISTIC FUNCTION OF NARRATIVES IN THE SACRED BOOKS AND RELIGIOUS-HISTORICAL EVENTS IN MODERN PERSIAN NOVELS
}

\author{
Sotiboldieva Sarvinoz Ruzievna \\ Professor, Doctor of philology sciences, Department of oriental languages \\ Tashkent State University of the Uzbek language and literature
}

Article DOI: https://doi.org/10.36713/epra4174

\begin{abstract}
Every nation has its own way of life, culture, spiritual and religious values. These values are also reflected in the fiction, which is the product of the artistic thinking of that nation. Since the creation of the Holy Qur'an, the Bible, the Torah, and the Psalms, they have played an important role in the lives of people who believe in a particular religion. One of the main reasons for this is the existence in the holy books of stories didactic in spirit about life and death, good and evil. The writers make effective use of these stories, as well as the exemplary lives of the prophets and religious historical events, in shaping the plot of their works, and in increasing the effectiveness of the ideas they put forward. Considered one of the hearts of ancient civilization, Iran is famous for its heroic spirit and epic traditions that glorify kings. But the twentieth century went down in history as the century in which moderntype novelism flourished in Iran. It was a new century for Iranian novelists to be recognized not only domestically but also globally. The purpose of the study is to shed light on the impact of religious narratives on the art of the work, their ideological and artistic function. The study found that sacred narratives given in the sacred books and the new interpretation of religious-historical figures in the modern Persian novels has significantly impacted on the styles of writers.
\end{abstract}

KEYWORDS: Qur'an, Torah, Bible, Modern Persian Romanism, Style, Abel and Cain, Archetype, Motive, Life of Prophets, Religious Story.

\section{INTRODUCTION}

In the literature of the peoples of the world, reference is often made to stories and narrations in religious books such as the Qur'an, the Bible, the Torah, and events related to the Prophets and their lives. The philosophical, spiritual, didactic content reflected in the stories of religious books has not lost its significance over the centuries. That is why writers and poets use them effectively to increase the impact of their works, to convey their ideas, thoughts, creative intent to the reader. It is recognized in science that the related aspects of literature and religion, the artistic reflection of the basic philosophical and moral views of religion in the literature of the peoples of the world and the East, the understanding of Muslim Eastern literature requires knowledge of the wisdom of the Qur'an [20:91]. It is not a novelty today that the topics of the Qur'an are widely used not only in the East but also in Europe. $[9 ; 10 ; 14]$ In the artistic thinking of the Iranian people, which is deeply rooted in the spirituality and culture of Islamic beliefs, reference to the Qur'an and religious stories also plays an important role. The themes of good and evil, goodness and depravity, kindness and back biting, generosity and envy, honesty and dishonesty, patience and purity reflected in the stories of the Qur'an have not lost their relevance today. 


\section{SJIF Impact Factor: 7.001| ISI I.F.Value:1.241| Journal DOI: 10.36713/epra2016 ISSN: 2455-7838(Online) EPRA International Journal of Research and Development (IJRD)

\author{
Volume: 5 | Issue: 8 | August 2020
}

- Peer Reviewed Journal

\section{II.LITERATURE REVIEW}

In the Study of Persian Novels Adam and Eve: Shahrnush Porsipur "Women without Men" [15]; Abel and Cain (The actual names are Khobil and Qobil, but we have decided to use the Abel and Cain as they are the same figures in both Islam and Christianity. Furthermore, these names are more popular and well-know for Anglophones across the Globe) : Abbas Marufi's Symphony of the Dead [12]; Bibi Maryam: Sadiq Chubak "Stone of Patience" [19], Shahrnush Porsipur "Women without Men" [15]; Stories about the devil, Satan: Tagi Muddarisi's "Yakolia and her loneliness" [3] and stories of a religious nature in general: Riza Amirkhani's "I" [2], Marjone Sotropi's "Persepolis" [18] - the plot of modern Persian novels played an important role in the construction, artistic technique. In such works, the myth of Mishi and Mashyone - Adam and Eve is widely used, while in the surrealist Hormuz Shahdadi's novel "The Night of Fear" [21], the stories of Abraham (a), Ishmael (a), Mother Hagar and Sarah are widely used. As part of the study, we will delve deeper into a few of these novels.

\section{III.ANALYSIS}

In Iran, which has long been world-famous for its poetry, a novel genre was formed in the early twentieth century that was new to the country. A series of novels created in the early stages of the development of Romanism (20-40 years) is on a religious theme, mainly covering the Prophet Muhammad (PBUH), imams and their way of life, the lives of their predecessors, and the details of the battle for Islam. Among the novels in this direction, the works of Zaynalobidin Rahnama "The Prophet" [5], "The Life of Imam Hussein" [6] were met with great interest by Iranians and foreign readers. In Iranian society, where Islamic beliefs have taken a leading position, it was natural that the novel, in which the lives of religious figures were artistically interpreted, would be warmly received. The plot and compositional aspects of the novel were specially studied by the Tajik orientalist G. Kadyrov [8]. Russian scholar J. Dorry also expresses his attitude to these novels. [4: 58-59] J. Dorry's remarks on the novel's novelty and the writer's novelty are particularly noteworthy here: "the distinctive feature of "The Prophet" is that it portrayed the founder of the Muslim religion and his followers, his predecessors, and their interpretation of their activity is free from any religious bigotry "[4:58]. J. Dorry draws attention to the uniqueness in the interpretation of the image of prophet Muhammad (PBUH). What draws our attention is the style used by the writer in shaping the composition of the novel. It is known that there are many works dedicated to the lives of prophets like Joseph and Jesus (more than 150 works dedicated to Yusuf/Joseph (pbuh) have been created in the world literature. [S.S.] There are also many works devoted to the life and career of Jesus as well; some of the examples are "A scene from the period or the stories of Isa ibn Hisham" by M.al-Muvaylihy, and "Isa- the son of humanity" by J.J. Jubron.).

\section{IV.DISCUSSIONS}

In the development of Iranian novelism until the first half of the twentieth century, among the novel-trilogies there is no series of novels based on the biographies of the prophets. Z.Rahnamo was one of the first to create a trilogy of novels related to the life of Muhammad (PBUH). The plot of the novel by Rahnamo was built upon the events (the discovery of a Zamzam well near Kaba by Abdulloh the son of Abdul Muttalib, Abdulloh's marriage to Omina, the birth of Muhammad (PBUH), the death of his parents when he was aged eight, the revelation of prophecy to Muhammad (PBUH) by archangel Jabroil/Gabriel (Volume I); The period up to the migration of Muhammad (PBUH) to Madina (Volume II) The events took place in Madina up to the death of Muhammad (PBUH) (Volume III) directly related to the life of Muhammad peace and blessings of Allah be upon him [5]. All of these were used as the devices that could provide the natural flow of the novel-trilogy in terms of semantic integrity and logical consistency. Although the plot of the novel is based on the stories of the prophets, the main difference is that the text of the novel contains examples from the works of famous Persian poets such as Rumi, Firdausi, Hafiz, and folk songs. The plot and composition of the novel are related to the biography of the protagonist, and the sequence of all events is placed in a way that is relevant to his life in terms of time. G.Kadyrov discovers that during the creation of the novel, the writer used more than a hundred sources of Western and Eastern historians, theologians, semi-historical and semi-mythical legends, hadiths, legends, historical and geographical information in the description of Firdavsy's «Shohnoma» and Nasir Khusrav's «Safarnoma» [8:24]. This also increases the value of the novel as a work of art, and helps to enrich its excitability.

The $50 \mathrm{~s}$ and $70 \mathrm{~s}$ of the twentieth century saw a significant shift in the way Iranian writers addressed stories in religious books. Taqi Mudarrisi (born 1932), a famous prose writer of his time, began this turn with his novel "Yakolia and His Loneliness»" [3]. The novel was named "Best Novel of the Year" in the magazine "سخن" ("Sokhan). The content of the work is enriched with Torah plots, philosophical observations, myths, and through them the universal social problems are described. It is noteworthy that Muddarisi narrated these problems in the language of the Torah, and this method led to the popularity of 
the author's work among the people. Observing the author's style, the Iranian critic H. Mirabidini writes that "the writer became a singer, seeking refuge in the Torah and weeping over the inevitable fate of man," as if the only way out for the frustrated intelligentsia was to seek refuge in the pits of history [22: 345].

The number of characters in the novel is not so great. The protagonist is Jacoli, the daughter of the king of Israel. She is exiled by her father for falling in love with an ordinary shepherd boy. On the banks of the "Obone" River, she meets an old shepherd. Satan appears in front of her in the guise of an old shepherd. He tells Jacoli an ancient legend about King Mikon's love for a woman named Tomar. According to legend, King Mikoh had a son named Azar, who, returning from one of the next battles, brought a woman as a gift for his father. King Mikoh falls in love with her. One day the messenger brings the message about Satan taking a woman as a maid from Sodom into his service and that the curse of the Creator is with her, that woman was that Tomor. The priests call her Satan's agent [3:17]. The people demand punishment from King Mikoh for Tomor. King Mikoh's various excuses do not deter them from their covenants. As a result, the king is forced to surrender in defiance of his inner inclination and because of the pressures placed on him. Tomor is captured and Mikoh is condemned to loneliness. Similarly, Yakulia, who had been banished to the wilderness, was alone. The novel states that Tomor was from the city of Sodom. Chapters 18 and 19 of Genesis, the first book of the Torah, deal with the city of Sodom. Sodom is the name of an ancient city that was destroyed by the Lord because of its sinfulness and savagery. The people living in this city were engaged in piracy and corruption (homosexuality). "And the Lord said: "there were many plagues upon Sodom and Gomorrah, and their sins were very great. Now I go down and see if the sighs that have reached my ears are true, if they have gone astray as I have heard. If not, I should know.'"[7: 645-646]. According to the Torah, Abraham prayed to God not to destroy Sodom and not to leave righteous servants in the midst of the wicked. Then the Lord says that if ten righteous people are found, He will save this city and sends two angels to know the real situation in the city. But the people in this city were really evil. As a result, only Lot and his daughters survived, and fiery sulfur was poured down from heaven on the city, and the city was razed to the ground. [7: 646; 11: 230-231]. The legend of Tomar and King Mikah also refers to Satan's deceptions, his misleading abilities. When Tomor reports the order of Mikah for Asobo, who brought the information about Satan being a human, to leave the city, Asobo compares his situation to that of the two angels who came to Lot's house. At the same time, the story of Lot in the Torah [7: 649] is fully incorporated into the text of the novel. The story of Lot's daughters getting their father drink wine up to the point he loses consciousness, and having intercourse with him which results them to get pregnant from their father is cited as a sign that King Mikoh's indulgence in alcohol will not lead to good results.

The content of Yakulia and Satan's conversation stems from the essence of Jehovah and Satan's rebellion against him in the Torah. According to the Torah, Satan tries to mislead man in various guises. In particular, the temptation of Adam and Eve in the form of a serpent to eat the forbidden fruit, the murdery between brother that began through the story of Cain and Abel, and so on, are all related to Satan's tricks. The fact that the shepherd is originally a devil is understood through his conversation. He speaks arrogantly to Yakolia for not fearing the Lord, and asks Yakolia a question, pointing to heaven, saying, "Why do you love the Lord?" and tries to plant the seeds of hopelessness, sadness, and insecurity into the heart of the girl by asking questions like that, and attempts to make the girl believe that she is alone. This man, who was called a shepherd at the beginning of the novel, was later directly referred to as Satan.

Satan in Muddarisi's interpretation is very close to that of character Satan in "Demon" by Russian poet M.Lermonotov in essence (1814-1841). Satan, as interpreted by M. Lermontov, also awakens hopes and dreams in the heart of a girl thirsting for love, and at the same time sows the seeds of sorrow and depression in her heart [23]. In Mudarrisi's interpretation, Satan is proud of his independence, his non-subordination to Jehovah, and considers Yahweh to be the enemy of beauty. His whole existence was filled with pride:

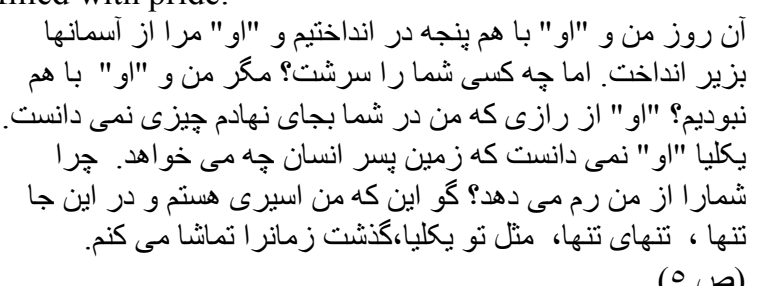

(ص. (ص)

Translation: That day I and He fought cats and dogs and He threw me from the Heaven to the Earth. But, Who created you? Weren't He and me together? He was completely ignorant of the secret I told you. Yakulia, He did not know what the children of Adam wanted from life. Why does he scare you from me so much? I am a lonely prisoner here, alone, just like you, Yakulia, watching the time passing. [3: 5]

In the novel, Muddarisi tries not to deviate from the plots of the Torah. For the problems that concern the author (Yahweh, love, sin-disobedience, 


\section{EPRA International Journal of Research and Development (IJRD)

loneliness, relationship with society) are eternal, and here the period is irrelevant. The role of Satan-related interpretations in the novel is replaced by artistic, lyrical episodes at times. In the creation of the psychological portrait of King Mikoh and Yakoliya, the writer uses image of the landscape, and lyrical poetic verses are also effectively used. The scene of Yakolia suffering in solitude on the banks of the Abone River is proof of our opinion:

$$
\begin{aligned}
& \text { غروب بر سينه خاموش افق بِر ده سياه مى زد. } \\
& \text { آسمان بازو متعجب برو هينه } \\
& \text { روى هر جيز خميده بود و ابانه تأ كبودى آباديها دور مى رفت و }
\end{aligned}
$$

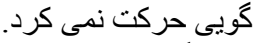

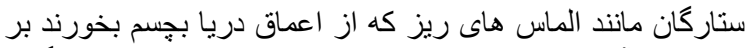

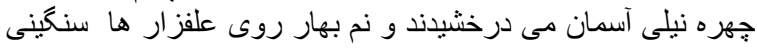

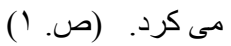
black curtain of the horizon. The sky opened, and he bowed in amazement over everything, and the blue color and prosperity of Obone became more and more distant, and seemed to cease to move. The stars looked like tiny diamonds taken from the bottom of a river and glistened in the blue sky. The humidity of the spring weighed heavily on the grass. " $(3: 1)$

Changes in Yakolia's mental state were described in a manner consistent with changes in nature. Also, in one of the scenes expressing King Mikoh's love for Tomor and his inner experiences, the following poetic verses are quoted:

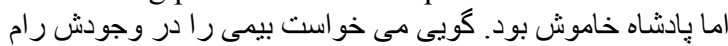

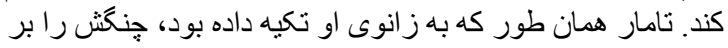

$$
\begin{aligned}
& \text { داشت و اين غزل سليمان ران را خو اندا: }
\end{aligned}
$$

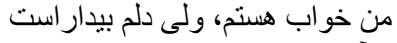

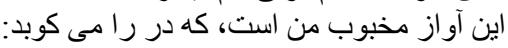

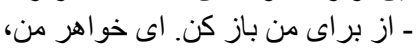

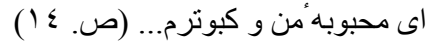

"But the king was sad. Tomor leaned on his knee, picked up the dust, and recited Solomon's ghazal:

I am asleep, and my heart is awake

The sound of knocking on the door - my dear lover.

Open for me, my dear sister, open that door,

You are my beloved, and my dove. [3:14].

Evils such as lust, satanic desires, and arrogance also determine the main idea of Bahrom Sodiqi's (1936-1984) novel "ملكوت" (Malakut) [16]. In the novel, reality and unreality are presented in a mixture of real life stories and myths. The events in the work begin at midnight, full of amazing mysteries. The novel consists of six chapters, and each chapter begins with verses from the Qur'an or lines or poetic verses taken from the Torah. For example, the first chapter is called "ج ين ح لولَّ (Jinn

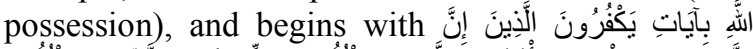

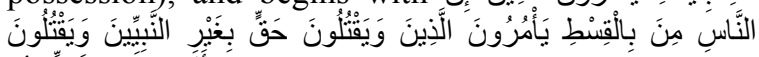
"Those who disbelieve in the signs of Allah and kill the prophets without right and kill those who order justice from among the people - give them tidings of a painful punishment".) The Noble Qur'an, Surah Ali 'Imran, 21 st ayah; [11]); the second chapter is about "J"م سرك ذ شت "The Adventures of M.L."), and it starts with the poetic lines of Mawlana Rumi’s “" (My secrets are closer than my moans); The third chapter is called " سد بزده " and begins with the last book of the Bible, "Revelation" [1: 167] - the prophecy of God to the apostle John ("Darkness of Heaven"), and similar titles are common to all chapters. The fact that the number of chapters in the novel is six also has a special meaning: the writer refers to the message in religious sources that God created the universe in six days. The novel is also based on the idea that the universe was created from two different parts (essences): the hidden world - the world of the unseen, and the visible world. The world of the unseen is the "world of angels"; hence the name of the novel is derived from that.

The events of the work take place in two spaces: outside the house (in the garden) and inside the house. There are 4 people in the garden: $\mathrm{Mr}$. Mo'vvadat (مودت means "friendship", "nobility" in Persian), Nashnas (ناس - ذاس - means anonymous or

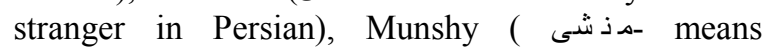
"secretary" in Persian), Chaquluv (جاق الـ و و stout, fat in Persian) and they are socializing in the garden. They are talking about some mysterious death, a crime that took place in the city. There are also 4 people inside the house: Dr. Hotam, who is a manifestation of Satan (خات م- means "judge",

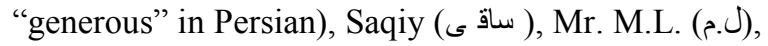
and Mr. Sheku (ش كو ). The behavior, actions, and appearance of the protagonists in the novel all have mystery and abstraction. For example, Mr. M.L. - his whole body is full of cuts and scars, and he keeps his cut body parts in an alcohol bottle. He also came to the doctor to amputate the last surviving part of his body (?!). He has been living in Dr. Hotam's house for 13 days, writing down his memories and feelings on a piece of paper. Meanwhile, Sheku and Saqiy are looking after him kindly. Saqiy is Dr. Hotam's unhappy wife. She was sentenced to death by injection of death for allegedly sharing a secret with Sheku. Not only the family, but many residents of the town were "gifted" by Dr. Hotam with a lethal injection. From outside, Monshiy wants to get closer to Dr. Hotam and learn his secrets. But the doctor does not let him in on the pretext that "whoever wants to go in must know nothing" [16:27].

"Perhaps the writer took these four concepts from Revelation to John, Apocalypse of John and his discoveries. In general, the number 4 in the novel is symbolic. The number four is one of the most important numbers in the Bible and is widely used. The fact that the Bible is in four copies proves the 


\section{EPRA International Journal of Research and Development (IJRD)

subject. The seventh chapter of the Bible, in Revelation chapter on page 1432, it states: "Then I saw four angels standing in the four corners of the Earth, holding the winds from the four corners of the Earth so that they would not blow over the Earth, the sea, the rivers, or any tree. There is also another point in the names of the three friends (Except the Stranger, the Stout, Munshiy and Muwaddat are followers of the devil), from cultural point of view "three friends" are the names of three trees: desire for ambition, long life and having virtues are indicated here.

In the novel, two worlds are mixed: the world of earthly slaves who fear death and dream of eternal life, and conversely, the world of Satan who is bored of eternal life. The fate of all those inside the house has the same ending - they pass away.

The fate of the outsiders is a bit different. None of them have a name. Their nicknames are used as their mask. Masks were used to reveal the character in their personalities. The lust of their souls always tells them that they should enjoy every minute, everything and anything, in every moment. The main thing that unites them is their extreme selfishness. At the same time, great sins are hidden behind these masks. For example, the Stout: he is actually a big trader, a selfish man who loves himself very much, and dreams of living a long life and living his life to the edge. He thinks of nothing but enjoying life. He is so concerned about his health that even when someone talks about his death or illness, he becomes embarrassed and feels vulnerable. The following scene shows this once again:

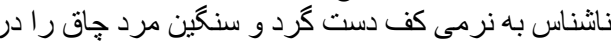

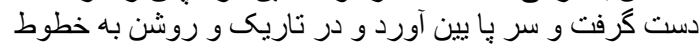

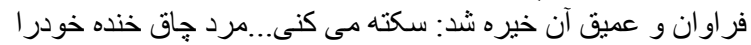

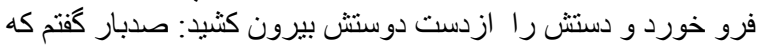

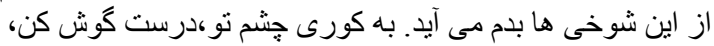

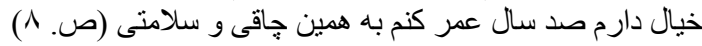
Translation: "The Stranger gently took the round and heavy hand of the Stout man, bowed his head, and in the dim light stared at the countless deep marks on his palm: -" You will have a heart attack in the future." The Stout man hid his laughter and took his hand from his friend's and said, "I've said a hundred times that I hate jokes like that." "I swear to you, listen carefully, I am going to live alive and well for another hundred years. " [16: 8].

The Stout has 7 sins: pride, lust, temptation, jealousy, anger, greed, laziness.

Monshiy, unlike the Stout, is a big fan of beauty. But he, too, was only in pursuit of pleasure because of Dr. Hotam's injections. These too will eventually leave their life one by one. Only the Stranger survives to the end of the work.

The fact that events take place in two different places (outside and inside) in terms of space shows that Dr. Hotam has two worlds (inner and outer) and that they do not complement each other, in other words, they are very distinctive from each other.

The main idea put forward in the novel is that man is not capable of changing the world in this life, the destiny of his life is determined by the Fate. In this world he is alone, defenseless, and forced to live only in suffering. There is no meaning of life in this world, evil reigns and it is always victorious. The only remedy is death.

Unfortunately, Sodiqi's novel «Malakut» was not completed. The author has fallen victim to his own mistrust and pessimism. He was so depressed that life and existence lost its meaning for him. The fate of many of his heroes in his works became his fate as well.

The methods used by the writer in the process of transforming the reality of life into an artistic reality play an important role in defining his artistic skills. One such method is the principle of using archetypes in the architecture of Persian novels. In essence, the concept called archetype in scientific language is nothing new for Persian literature. Persian novels have always been dominated by myths and legends, which are the source for the 'first image', the pattern 'plot and plot situations', which is now implied by the concept of archetype.

In the next novel, "The Symphony of the Dead", [12] Abbas Marufiy (1958) ${ }^{1}$ begins his work with a story about Abel and Cain in the Qur'an (Qur'an, Surat al-Ma'ida, 27) and introduces the reader to the story of brother's killing each other in order to mentally "prepares" the plot of his work. The main conflict in the plot of the work is reflected in the relationship between the brothers Urhan (اور هان) and Aydin (ين آيد). The important role of the story "Abel and Cain" in the Qur'an as an archetypal motif is shown in the following:

First, this archetype-motif plays an important role in defining the idea of the work. Showing the consequences of ignorance and jealousy are the main idea of the work. The writer did not refer to this old story in vain. The books claim that "the conflict between Cain and Abel was the first struggle between good and evil" [1:39], and that it has been "living" and "repeating" in different ways and forms for centuries. In the character of Urhan, we

\footnotetext{
${ }^{1}$ Ma'rufiy Abbas (معروفى عباس) is one of the most modern avant-garde Iranian novelists. He entered the world of literature with his stories like "روى بيش" "ب "نسل آخرين" ("Face to Face with the Sun", 1980), "برتز" ("Last Best Generation", 1987), "س عطر "بن "'The Lilac Scent", 1992). ), novels such as "بلونر ال سطان" (Year of Rebellion) and "مردكان سمفونى" (Symphony of the Dead, 1989) and a number of poems.
} 


\section{EPRA International Journal of Research and Development (IJRD)

see the qualities of Cain, who was mentally ill, prone to evil, tempting to lust and sin. Motives such as Cain's endless hatred and envy of his brother Abel and his murder are also repeated in Urhan's relationship with his brother Aydin in the "Symphony of the Dead". However, in contrast to the story mentioned in the Qur'an in the novel, Aydin ends up to be insane even though he is not physically dead, his soul gets "vanished". Due to the oppression of his brother Urhan and his father, his talent, which had just sprouted, was destroyed.

Second, the archetype-motif is one of the factors ensuring the compositional integrity of the novel. The novel consists of five parts, the first and last part of which serves as the main modeler of the story. The essence of this stereotyped story is revealed through archetypal motifs. That is, one of the main antagonists, Urhan's intention to kill his brother Aydin, and his efforts to carry out this heinous intention, and how they ended, forms the plot of the story.

Third, the archetypal motif plays an important role in determining the pathos of the novel. "The Symphony of the Dead" is dominated by tragic pathos. The fate of all the main heroes ends tragically. Urhan suffers from a guilty conscience and, remembering his deeds in an abandoned part of the city, freezes to death in the bitter cold of the morning, Ayda (Aydin's twin sister) burns herself alive, and Yusuf (Aydin's brother) falls from the roof as a child, he gets severely injured and dies. Aydin goes crazy. However, all tragedies are directly or indirectly linked to Urhan. Here is an episode from the work about the fate of the people in their family:

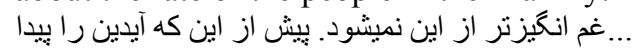

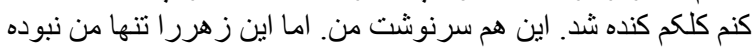

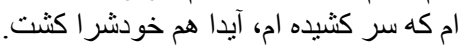

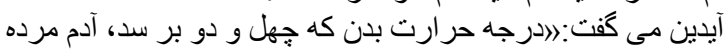

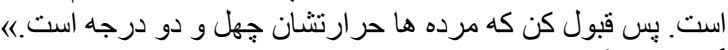

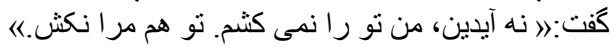

Translation: It can't be worse. My soul came to my throat until I found Aydin. That's my fate. But I was not the only one who tasted this poison, and Aydo also committed suicide.

"If a person's body temperature reaches 42 degrees, he dies. In that case, admit that the body temperature of the corpses will be 42 degrees," said Aydin. "No, I'm not going to kill you, Aydin. Don't kill me either." - He said.

Tragedy is manifested not only in the fate of the heroes, but also in the social relations in society, in the attitude of the father (Jobir Urhan) and his children and wife, who are ignorant due to illiteracy. At every step, Jabir humiliates his son Aydin, who is interested in poetry, art and books. Urhan, on the other hand, is the opposite of Aydin, ignorant and rude, with all the same characteristics as his father.
The only girl in the family is Ayda, Aydin's twin, who is similar to him in many ways. His father treats her as a useless object as well. Ayda grows up missing the love of her parents. The mother, on the other hand, mourns the loss of her children but cannot help them either.

Fourth, the archetype-motif was effectively used to create conflict and strong drama, which is very important for a work of art. The main conflict in the play is between Aydin and Urhan, Aydin and Jabir. The conflict between Aydin and Urhan is caused by a strong jealousy of Urhan's brother (because Aydin is talented, he writes poetry, his mother always pays more attention to him than Urhan) and the inheritance from his father, the conflict between Aydin and Jabir is the result of the father's ignorance (he does not understand poetry, ignores his son's talent, considers education and reading books to be "useless work", and he requires him to pursue a profitable profession). The following scene is evidence of the father's place in the family, his character, and his different attitudes toward his children in the family:

$$
\begin{aligned}
& \text { >ايوسف را مرده فرض كن. يوسف كه آدم نيست. خودت }
\end{aligned}
$$

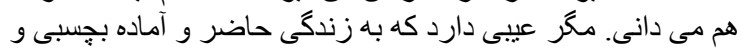

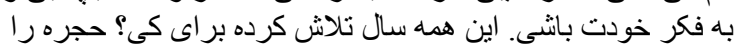

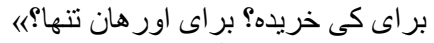

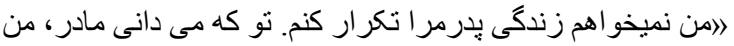

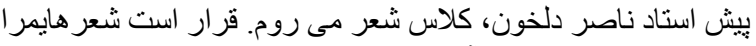

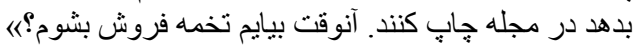

$$
\begin{aligned}
& \text { Translation: "Suppose Yusuf is dead. }
\end{aligned}
$$

Because Joseph is not a man. You know that. What is wrong with a person who clings to life with his teeth and nails and cares about himself? Who did he work for all his life? Who did he buy the building for? Only for Urhon?"

"I don't want to repeat my father's life. Mother, you know, I go to poetry classes of teacher Nasir Dilhun. My poems are to be published in a magazine. Why should I come and sell seeds?" [12: 155]

In order to enhance the drama in the work, the author introduces the scene of burning Aydin's books and poems by Jabir and a monologue by Aydin's wife Surmelina (a Christian girl of Armenian descent), which forms the whole third part of the work. Through this monologue-observation, the tragedies that befell upon the family of Jabir Urhans are assessed objectively, critically and sharply.

The story of the Blessed Virgin Mary is also one of the most frequently used religious stories by Iranian novelists. In the 1967 novel صد بور سدنى" (The Patient Stone) [19] by the great Iranian prose writer Sadiq Chubak (1916-1998), we can see an appeal to the story of the Blessed Virgin Mary in the interpretation of one of the protagonists, Gavhar. The novel's title and main motif are taken from a famous Persian tale about a man who went to a stone which 


\section{SJIF Impact Factor: 7.001| ISI I.F.Value:1.241| Journal DOI: 10.36713/epra2016 ISSN: 2455-7838(Online) EPRA International Journal of Research and Development (IJRD)

can patiently listen to his sufferings. At the heart of the novel is the problem of the value of human life in general. Human life has its value, whether it is sad, full of sorrow, or helpless or poor. The life of each protagonist in the novel is manifested either as an expression of trampled honor, or grief, or weakness, or a lie.But what unites them all is infinite PATIENCE. The concept of "patience" has a philosophical meaning in the interpretation of the writer. The "Stone of Patience" is not a fairy tale, so it is a human, not a stone, that must be endured to such grief. Jahansultan, who had endured the immoralities of the world all his life despite the fact that his body was rotting from wounds and ridicule, Gavhar, who could not resist the humiliation of her masters by her unconditional obedience to religious beliefs and customs, and was eventually poisoned by a doctor, Kokulzari, who dreamed of a goldfish and eventually sank into the pool to catch it - all of them died. In short, the limit of human patience, that is, the society which causes him to feel lose his temper as the cup of his patience is filled and can keep no more of anything, and, finally, the depression of the human will in relation to it, determine the main idea of the work. At the age of 12, she was given as a fourth wife to a wealthy merchant who wanted to "get an heir-bearing wife" and was later rejected by her husband and parents due to an unfortunate accident to her newborn child. The victim, Gavhar, and her tragically deceased son (Kokulzari) are embodied in the image of Jesus in the arms of the Blessed Virgin Mary. The author also cites the story of Adam and Eve (Mishe and Moshyone) at the end of the novel. The purpose of this is to show how negative the oppression, injustice and cruelty of the human race, which is descended from one parents, is.

One of the modern writers, Shahrnush Porsipur, also creatively used the symbol of purity associated with the Virgin Mary in his novel " زذنان "مردان بـ دون (Women Without Men) [15]. It is no exaggeration to say that Porsipur revolutionized novel writing on the women's topic with this novel. The main theme of the novel is the WOMAN and her mysterious world. The main idea of the novel is to glorify pure love, free from all kinds of hatred and lust. The protagonists of the novel are women who have rebelled against the society in which they live and the laws that affect their female destiny. The volume of the novel is not large, only 140 pages. The protagonists of the work are also five Iranian women, and the chapters of the novel are named after them:

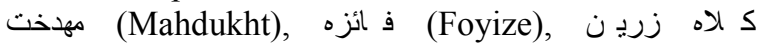
(Zarrinkuloh), موذس (Munis), لـ فا ف رن (Farrukhliqo).

These five women have their own destiny. These roads connect in one place in the GARDEN built by Ms. Farrukhliqo. Events took place in the lives of these women lead them to leave their homes to express their dissatisfaction. One of them were humiliated at an early age (Foyize), deceived by their relatives or trustees (Mahdukht), one of them was forced into prostitution by fate, another was severely beaten (Zarrinkolah), and the other was a teacher (Munis) who was deprived of the beauties of her life.

In the novel, Porsipur introduces the images of the Garden and the "the people of garden" as a symbol of the pure love, pure, warm relationship she dreams of. The garden is located in the Karaj area outside of Tehran, where women build the society of their dreams. The novel consists of several chapters, each of which tells the story of the fate of one of the heroes of the events. It is in this garden that reality is replaced by mysticism. For example, one of the protagonists, Mahdukht, declares herself as a "tree" in the garden and says that she will give birth to his "pure fruit" without any close relationship, for which she will have to "sow" her feet to the ground [15: 127]. And she gives birth to her own flowers. In the eyes of Porsipur, the tree that has become a mahdukht is embodied as a symbol of femininity, love without animal lusts. On the basis of this symbolism, there is a reference to Mary, the only woman mentioned in the Qur'an (Surat at-Tahim, 12; Surat al-Anbiya, 91; Surat al-Imran, 35, 42, 43) and her attributes.

\section{V.CONCLUSION}

In Iranian novels references to, which are mainly written on a historical-religious theme and in a surrealistic style, the stories in the holy books, the events in the lives of the Prophets, and historical events of a religious nature are observed.

The main protagonists of historical religious novels are mainly the Prophet Muhammad (PBUH), imams, companions of the prophet Muhammad (PBUH), and caliphs. These novels have a biographical character, and their plot is based on the events that took place with the family, relatives and companions of the Prophet (PBUH). The novels use works of various religious nature, legends and stories, historians of the West and the East, theologians, semi-historical and semi-mythical narrations, hadiths, legends. The works convincingly describe the details of holy cities such as Mecca, Medina, Karbala, the customs, rituals, and clothing of the time of the Prophet (PBUH), which are of great geographical and ethnographic importance. The novels are not detached from classical traditions. Firdavsi's "Shohnama" and Nasir Khusrav's "Safarnama" were also effectively used in them.

The story of Abel and Cain, chosen by Abbas Marufiy as an archetypal motif in "The Symphony of the Dead", plays an important role in defining the idea of the work, ensuring compositional integrity, defining the pathos of the work, 
strengthening conflict and drama, defining the writer's creative direction. All this together played an important role in the realization of the author's creative intention to express through artistic scenes that ignorance, the tendency to oppression are ancient human habits and their negative consequences in any period can lead to tragedies.

In "The Stone of Patience", S. Chubak tries to be based on real facts, using traditional and heroic epic methods, but the influence of the concepts of irrationalism and existentialism is still noticeable. This is manifested in the chaotic description of the world, in the fact that the heroes think that their minds are depressed, and that the tragic end of existence is inevitable. The stories of the Virgin Mary, Eve, and Adam are of great importance in expressing the writer's state of mind.

The content of the story of the Blessed Virgin Mary is creatively used in the depiction of pure love, free from all hatred and lust, which is the main idea of the novel "Men without Women" by Sh. Porsipur. The authoress creatively interprets the content of this story and through it shows the attitude towards women in her society.

Hence, it can be concluded from the above that the stories narrated in the holy books, historical events of a religious nature and the life of the Prophets (peace and blessings of Allah be upon all of them), their universal humanistic ideas and didacticphilosophical content serve for the spiritual maturity of mankind regardless of which religion they follow. 